\section{Akuttmedisinsk turnusarbeid i Finnmark}

ORIGINALARTIKKEL

\section{KAJA HANSEN HUNNÅLVATN}

Det helsevitenskapelige fakultet

Universitetet i Troms $\emptyset$ - Norges arktiske universitet

Hun har deltatt i planleggingen, utført datainnsamling, gjort primær analyse, deltatt i

manuskriptutarbeidingen og har godkjent innsendte manusversjon.

Kaja Hansen Hunnålvatn (f. 1991) er turnuslege ved Helgelandssykehuset Mosjøen.

Forfatter har fylt ut ICMJE-skjemaet og oppgir ingen interessekonflikter.

\section{DANIELA IVAN}

Det helsevitenskapelige fakultet

Campus Hammerfest

Universitetet i Troms $\emptyset$ - Norges arktiske universitet

Hun har deltatt i planleggingen, i dataanalysen og i manuskriptutarbeidingen og har godkjent innsendte manusversjon.

Daniela Ivan (f. 1971) er spesialist i allmennmedisin, fastlege ved Allmed legesenter i Hammerfest og universitetslektor.

Forfatter har fylt ut ICMJE-skjemaet og oppgir ingen interessekonflikter.

\section{TORBEN WISBORG}

E-post: torben@wisborg.net

Akuttavdelingen

Finnmarkssykehuset, Klinikk Hammerfest

og

Universitetet i Troms $\emptyset$ - Norges arktiske universitet

og

Akuttmedisinsk-anestesiologisk forskningsgruppe

Institutt for klinisk medisin

Universitetet i Troms $\emptyset$

og

Nasjonal kompetansetjeneste for traumatologi

Oslo universitetssykehus, Ullevål

Han initierte prosjektet og har deltatt i planleggingen, i dataanalysen og i manuskriptutarbeidingen og har godkjent innsendte manusversjon.

Torben Wisborg (f. 1956) er overlege og professor. Han er leder for Nasjonal kompetansetjeneste for traumatologi.

Forfatter har fylt ut ICMJE-skjemaet og oppgir ingen interessekonflikter. 


\section{BAKGRUNN}

Det er ønskelig at leger på vakt i kommunal helsetjeneste deltar på utrykninger i akutte situasjoner. Hvor ofte leger rykker ut, har tidligere vist seg å variere. Vi ønsket å undersøke nyutdannede legers forventninger til og erfaringer med akuttmedisin og ambulanseutrykninger før og etter turnustjenesten.

\section{MATERIALE OG METODE}

Alle de 23 turnuslegene som skulle gjennomføre kommuneturnus i Finnmark i perioden 2015-16 besvarte et spørreskjema og deltok i fokusgruppeintervju før turnustjenesten. 21 av turnuslegene deltok i fokusgruppeintervjuet etter turnustjenesten. Hver lege deltok i to intervjuer. Vi analyserte transkripsjonene fra fokusgruppeintervjuene med «databasert teoriutvikling» (grounded theory, GT).

\section{RESULTATER}

Spørreskjemaet før kommuneturnus viste at turnuslegene følte behov for mer trening $\mathrm{i}$ venekanylering og i teamarbeid. Forventninger de hadde til utfordringer ved utrykning er best karakterisert ved kjernekategorien «Kan jeg gjøre noe nytte?» fra fokusgruppene før turnustjenesten. Etter kommuneturnus, derimot, passet kjernekategorien «Det gikk jo tross alt bra» best. Ved kort transporttid og ved god kjennskap til enkeltpasienter valgte enkelte av legene å avstå fra utrykning.

\section{FORTOLKNING}

Gjennom kommuneturnustjenesten gikk turnuslegene fra å være engstelige for å være overflødig til å bli seg bevisst sin rolle i utrykninger. Studien viser at det er behov for mer $\emptyset$ ving på enkelte praktiske prosedyrer og at legene trenger å bli bedre i ikke-tekniske ferdigheter. Det kan skje gjennom trening i teamlederfunksjon før kommuneturnus.

En velfungerende akuttmedisinsk kjede utenfor sykehus i den første fasen av alvorlig sykdom eller skade er viktig for at befolkningen skal få rask og kompetent hjelp i akutte situasjoner. Kommunal legevakt og legevaktsentral utgjør sammen med lekfolk, medisinsk nødnummer 113, kommunal legevakt og ambulansetjenesten viktige tidlige ledd i kjeden.

I prehospital akuttmedisin avgjør legevaktsentralen og AMK-operatørene hvorvidt legevaktlege skal varsles sammen med ambulanse eller ikke (1). Forskrift om krav til akuttmedisinske tjenester utenfor sykehus krever at den kommunale legevaktordningen dekker behovet for øyeblikkelig hjelp, i tillegg til at lege på vakt er tilgjengelig på helseradioen, nå Nødnett Helse (2). Det er også et krav at aktørene legger til rette for trening i samhandling (2).

Det er tidligere vist at lege på vakt i kommunal helsetjeneste ikke alltid blir med på utrykning ved hastegrad akutt. Det kan være flere årsaker til hvorfor enkelte velger å avstå fra dette $(3,4)$. Både etablering av stadig større interkommunale legevaktdistrikter, store avstander og redsel for samtidighetskonflikter, mer selvstendig og bedre trent ambulansepersonell, geografiske forhold, manglende varsling og annet kan påvirke legens avgjørelse.

Målet med denne studien var å undersøke nyutdannede legers forventninger og holdninger til deltagelse i utrykning og deres erfaringer med akutte situasjoner og utrykning etter gjennomført turnustjeneste i et stort fylke med lang transportvei til sykehus. 


\section{Materiale og metode}

Informantene var alle de 23 turnuslegene i kommuneturnus i Finnmark i perioden september 2015 til februar 2016. Ved første intervju deltok alle, ved andre intervju 21, da to ikke hadde mulighet til å delta. De ble delt inn i tre grupper ut fra arbeidssted. Rekruttering til studien skjedde via veilederne for turnuslegene i kommuneturnus.

Intervjuene ble gjennomført ved planlagte samlinger ved oppstart av kommuneturnus tre steder i fylket, utenfor sykehusene. Andre intervjurunde ble for to av gruppene gjort ved den avsluttende turnussamlingen, for den tredje gruppen via lyd-bilde-konferanse.

\section{SPØRRESKJEMAET}

Turnuslegene besvarte et spørreskjema før kommuneturnus. Det ble utarbeidet etter et litteratursøk og ut fra på forfattergruppens samlede erfaringer. I spørreskjemaet beskrev turnuslegene hvor trygge de var på sine egne ferdigheter og på fremtidig deltagelse $\mathrm{i}$ utrykning (fig 1 ).

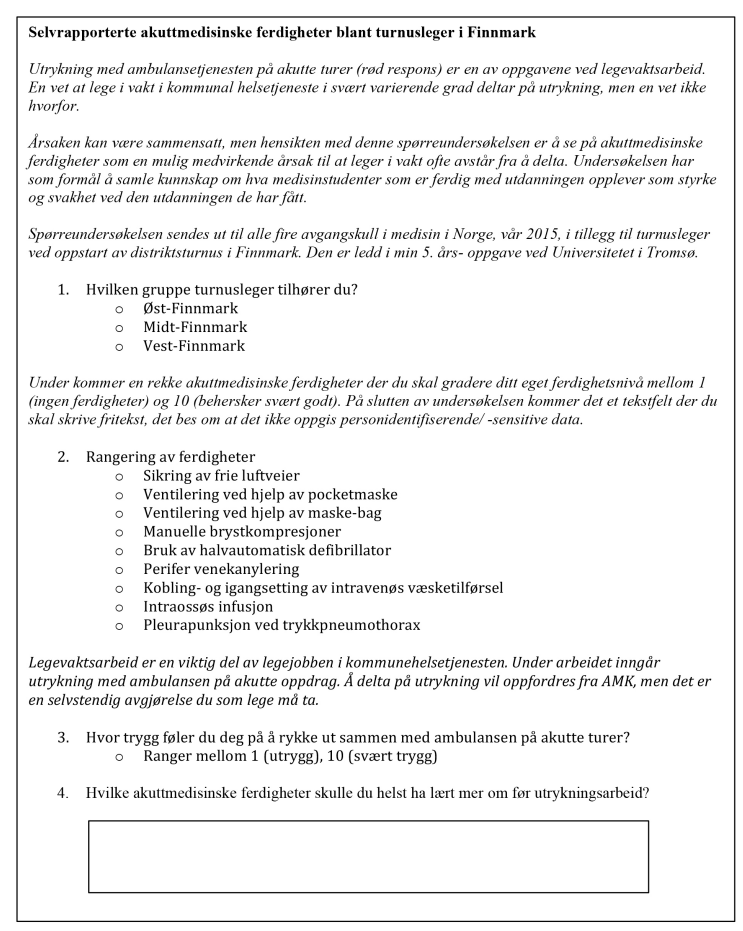

Figur 1 Spørreskjemaet som ble sendt alle informantene rett før start på kommuneturnus

Vi brukte en Likert-skala med forankringer på verdien 1 (behersker ingen ferdigheter) og 10 (behersker svært godt) for beskrivelse av hvor trygge de var på egne akuttmedisinske ferdigheter og hvor trygge de var når de måtte rykke ut med ambulanse $(1=$ utrygg, $10=$ trygg) (5). Turnuslegene beskrev i et fritekstfelt hvilke akuttmedisinske ferdigheter de gjerne skulle ha øvd mer på før de måtte ut på utrykning.

Spørreskjemaene ble delt ut like før kommuneturnus.

\section{FOKUSGRUPPEINTERVJU}

Fokusgruppeintervjuene ble gjennomført ved innledningen og avslutningen av turnus i kommunehelsetjenesten med samme gruppe turnusleger (6). De var fordelt på tre grupper 
ut fra geografisk tilhørighet i fylket. Gruppestørrelsen varierte mellom fem og åtte.

Det ble avholdt to intervjuer per gruppe, totalt seks intervjuer, i starten og i slutten av tjenesten. Gruppene var lokalisert i Øst-, Midt- og Vest-Finnmark. Intervjuene tok fra 34 minutter til én time. Alle ble gjennomført av en av forfatterne (KHH). Intervjuguiden er gjengitt i ramme 1 og ramme 2.

RAMME 1 SP ØRSMÅ SOM BLE DRØFTET UNDER FOKUSGRUPPEINTERVJUET MED TURNUSLEGENE FØR KOMMUNETURNUS

Følgende spørsmål var veiledende under intervju ved oppstart av kommuneturnustjeneste:

1. Hvordan opplever dere det/hvilke forestillinger har dere om det å skulle bli varslet av lege-ambulansealarm?

2. Hva tenker dere er med på å bestemme om dere skal bli med på utrykning?

3. Hva tenker dere er de største utfordringene ved å delta på utrykning?

4. Hvordan kunne dere eventuelt blitt bedre forberedt på denne oppgaven?

RAMME 2 SPØRSMÅL SOM BLE DRØFTET UNDER FOKUSGRUPPEINTERVJUET MED TURNUSLEGENE ETTER KOMMUNETURNUS

Følgende spørsmål var veiledende under intervju etter endt kommuneturnustjeneste:

1. Hvilke utfordringer har dere hatt i forbindelse med utrykning med ambulansen på akutte turer?

2. Har dere noen ganger latt være å bli med? Hvis ja; hvorfor?

3. Hva har vært med på å bestemme om dere skulle bli med ut?

4. Hvordan kunne du blitt bedre rustet til oppgaven?

Intervjuene ble tatt opp på lydfil og transkribert ord for ord straks etter gjennomføring (KHH). Videre koding og analyse ble gjennomført av KHH og TW med utgangspunkt i databasert teoriutvikling (7).

Vi fant meningsbærende ord og fraser i den transkriberte teksten (indikatorer), som ble sortert inn i kategorier som beskrev felles kvaliteter. Disse ble igjen delt inn i hovedkategorier, og til slutt i én kjernekategori. Sitatene og kategoriene ble i gjentatte runder satt opp mot det transkriberte datamaterialet for å sikre at analysen reflekterte det faktiske innholdet $\mathrm{i}$ turnuslegenes utsagn.

\section{ETIKK}

Undersøkelsen ble vurdert som ikke fremleggingspliktig av regional etisk komité nord (12.5.2015 2015/827/REK nord), og Norsk senter for forskningsdata (NSD, tidligere Norsk samfunnsvitenskapelige datatjeneste) bekreftet at det ikke var behov for registrering der (telefonisk meddelelse mai 2015). Alle informantene samtykket til deltagelse etter skriftlig informasjon og signerte samtykkeskjema før intervjuene. Alle data ble anonymisert. 


\section{Resultater}

\section{SP ØRRESKJEMA}

Resultatene fra spørreskjemaet før kommuneturnus viste at turnuslegene var tryggest når det gjaldt sikring av frie luftveier og i å utføre brystkompresjon, men følte at de ikke behersket intraosseøs infusjon og pleurapunksjon (fig 2, tab 1).

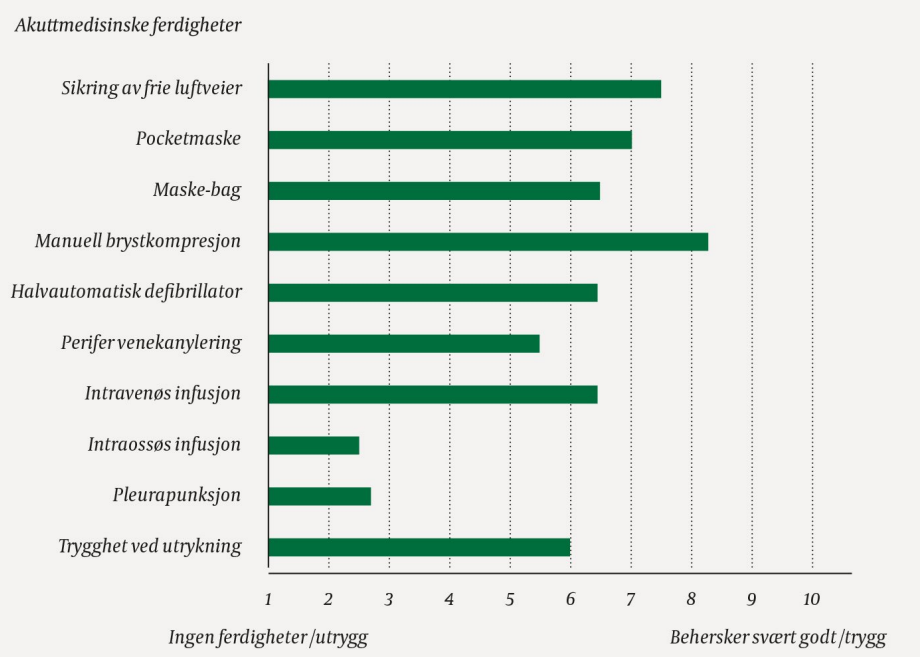

Figur 2 Turnuslegenes vurdering av egne ferdigheter før start på kommuneturnus. X-aksen gjenspeiler gjennomsnittsverdien av responsen på en Likert-skala (5)

\section{Tabell 1}

Turnuslegenes ønsker om ytterligere trening før start på kommuneturnus, anført i fritekstfelt i spørreskjema. 23 respondenter. Antall ganger ønsket = antall ganger $ø$ nsket er nevnt i fritekstfeltene

\begin{tabular}{|ll|}
\hline Ferdighet & Antall ganger $\emptyset \mathbf{n s k e t}$ \\
\hline Teamtrening & 5 \\
\hline Pediatriske kasus & 3 \\
\hline Primærundersøkelse & 2 \\
\hline Endotrakeal intubasjon & 2 \\
\hline Administrasjon av trombolytisk behandling & 1 \\
\hline Håndtering av synlig blødning & 1 \\
\hline Vakuumspjelk- og madrass & 1 \\
\hline Håndtering av epilepsi & 1 \\
\hline Medikamentadministrering & 1 \\
\hline
\end{tabular}

\section{FOKUSGRUPPEINTERVJU}

Intervju før kommuneturnus. De første fokusgruppeintervjuene med turnuslegene resulterte i kjernekategorien «Kan jeg gjøre noe nytte?». Denne kjernekategorien ble videre klassifisert i underkategoriene «Erfaring», «Ferdigheter», «Logistikk», «Tillit til andre yrkesgrupper» og «Egne hensyn». Disse kategoriene er beskrevet i mer detalj i det følgende.

«Erfaring». Turnuslegene hadde en generell forestilling om at erfaring og kjennskap til pasientene kunne være medvirkende til at enkelte velger å avstå fra utrykning. De dro paralleller til sykehusturnus, der de var usikre i starten, men ble mer erfarne i løpet av turnustjenesten. Legene var spente og nervøse før de skulle ut i den nye arbeidssituasjonen, og tanken på mye ansvar og frykt for å bli overflødig preget forestillingene deres.

Deltakelse på utrykning har sikkert noe å gjøre med hvor erfaren man er. Altså, jeg kommer 
jo ikke til å tørre å si nei. Mens leger som er mer erfarne sier nok fortere «nei det her har jeg vært borti før, jeg ser dem på kontoret når de kommer inn til meg». (Kvinne 1, gruppe 2)

«Ferdigheter». Det var generell enighet blant deltagerne om at de hadde fått tilstrekkelig opplæring i de fleste praktiske ferdighetene. Det å skulle samarbeide med erfarent ambulansepersonell opplevdes som en stor trygghet. Likevel skulle de gjerne ha øvd mer på medikamenthåndtering, perifer venekanylering, intubasjon, kritisk dårlige barn og avansert hjerte-lunge-redning før kommuneturnus.

Sånn ferdighetsmessig så tror jeg vi stort sett har fått god trening på det meste i turnus. (Mann 2, gruppe 2)

Før sykehusturnus hadde vi én gjennomgang av AHLR da vi begynte medisinsk turnus, hvis en da ikke har vært borti [hjerte]stans i løpet av det halve året i turnus, så har en heller ikke noe mer trening. Så hvis en skulle ha forberedt seg bedre, så er det kanskje et tiltak å legge inn hyppigere AHLR- øvelser. (Kvinne 3, gruppe 1)

«Logistikk». I Finnmark er det store geografiske og værmessige utfordringer. Frykt for samtidighetskonflikter sto sentralt som medvirkende årsak til å avstå fra utrykning. Turnuslegene mente at de har lite å bidra med dersom det er kun kort vei inn til legevakt eller sykehus og at responstiden kan bli lengre dersom legen må hentes først.

Hvis jeg får meldt en pasient som kan høres fredelig ut, må jeg kanskje gjøre en vurdering på om det er så alvorlig eller viktig at jeg tør å la resten av kommunens befolkning gå uten lege i to timer. (Kvinne 2, gruppe 1)

«Tillit til andre yrkesgrupper». På grunn av ambulansepersonellets lokalkunnskap og medisinske kompetanse hadde turnuslegene spesielt stor tillit til denne gruppen og fant det trygt å være med dem på utrykning. Flere nevnte at de hadde hatt lite trening $\mathrm{i}$ teamarbeid og teamledelse. Dette kunne være en medvirkende faktor til usikkerheten.

Det lille jeg har jobbet med ambulansepersonell... De har jo sett alt! ... Gjerne flere enn én gang. Så man lener seg veldig på dem. I hvert fall når man er ute. Så det faglige er ikke det som bekymrer meg mest, for da vet jeg liksom at dem er veldig god å ha! (Mann 3, gruppe 3)

«Egne hensyn». Turnuslegene hadde tanker om at leger på vakt prioriterer bort utrykningsarbeid av hensyn til egne arbeidsforhold. De fleste allmennleger i Finnmark skal på jobb og har full liste dagen etter legevakten. Legene så for seg at belastningen kunne gjøre at man avsto fra utrykning. I tillegg hadde de på forhånd opplevd episoder og hørt historier fra et rus- og psykiatrimiljø i fylket som kunne være vanskelig å håndtere prehospitalt.

Hvis man skulle etterspurt noe opplæring, så kunne jeg tenkt meg å hatt et sånt psykiatri/rus-kurs. For det er det jeg synes er mest ubehagelig, og det har vi ikke så mye av... Jeg har hatt litt av det på sykehus da. Men hvordan håndtere det her oppe og hvordan vurdere suicidalitet og sånt, det er fryktelig vanskelig. (Kvinne 4, gruppe 3)

Intervju etter kommuneturnus. Ved analyse av fokusgruppeintervjuene gjort etter turnus fremsto «Det gikk jo tross alt bra» som kjernekategori. Den ble videre forklart av underkategoriene «Erfaring», «Ferdigheter», «Logistikk» og «Tillit til andre yrkesgrupper».

«Erfaring». Turnuslegene beskrev at erfaring hadde hjulpet dem til å bli tryggere i det medisinskfaglige arbeidet, i den nye rollen og i teamarbeid. Frykten som legene satt med før kommuneturnus, ble for de flestes vedkommende mindre, og de følte seg bedre rustet til å vurdere behovet for å delta i utrykning.

Mye er liksom en algoritme, så når man har vært utsatt for det én gang, så senkes skuldrene litt til neste gang. (Kvinne 1, gruppe 3)

Før var det sånn; hvis noen blir dårlig i det flyet her; hva gjør jeg da? Men nå er jeg litt sånn; det går bra. Da følte jeg at jeg har lært noe da ... (Kvinne 2, gruppe 3)

Enkelte av kommunene i Finnmark har lokale retningslinjer om at lege i vakt skal være med 
på utrykning hvis lege-ambulanse-alarmen går. Turnuslegene i disse kommunene deltok derfor på alle turer med hastegrad akutt. Dette omfattet noen få av legene. Andre fikk spørsmål fra AMK-sentralen om å bli med og måtte ta en selvstendig avgjørelse.

Enkelte av turnuslegene oppga at de noen ganger hadde latt være å delta på utrykning, men mente likevel at de hadde lavere terskel for å rykke ut enn de mer erfarne legene, som har bedre kjennskap til pasientene.

Vi merker jo at vi har jo mye lavere terskel for å bli med enn de andre legene som er der fast. Det er enkelte av dem andre som konsekvent aldri blir med på utrykning. (Mann 1, gruppe

2)

Jeg har valgt å avstå og heller få de inn på sykestua for undersøkelse. Men det har kanskje vært sånn type pasienter som du har inne ti ganger med samme symptomer, hver gang har det vist seg at det ikke har vært somatisk sykdom. (Kvinne 1, gruppe 1)

«Ferdigheter». Legene erfarte at rollen som medisinsk ansvarlig utenfor sykehus tok mye tid. De erfarte også at deltagelse i konkret behandling var mindre påkrevd. Dette førte til at behovet for praktiske ferdigheter ble mindre.

God opplæring i ferdigheter knyttet til overgrep og voldtekt samt hvordan man møter pasienter i de mest sårbare situasjoner var et savn.

Ofte, hvis det er en situasjon hvor mye skal skje på en gang; det skal legges kateter, blodprøver skal tas... Hvis du skulle gjort alle de praktiske tingene, så hadde det tatt veldig lang tid. For du har på en måte andre oppgaver som kommer først da, som ta en anamnese, få det skrevet ned, ta noen telefoner...(Mann 1, gruppe 3)

«Logistikk». Utfordrende vær og geografiske forhold førte i kombinasjon med få ressurser til at det var vanskelig å løse logistiske problemstillinger. Legene ble gjennom dette nødt til å samarbeide med flere instanser i lokalsamfunnet. På korte utrykningsturer valgte flere heller å møte pasientene på legevakt enn å bli med på utrykning - for å korte ned på utrykningstiden og fordi de følte at de ikke hadde noe mer å bidra med før og under transport inn til legevakt.

Administrasjon og logistikk... Det er vanskelig... Det er kanskje det vanskeligste med hele jobben. Det tar utrolig lang tid. Hvis pasienten er dårlig og du må vente, det er stress. Det er det verste med å gå vakt synes jeg. (Kvinne 3, gruppe 3)

Der jeg jobber har jeg måttet rekvirere brøytebil for å komme oss til på utrykning. (Mann 2, gruppe 2)

Flere opplevde at hovedjobben deres på utrykning var å prate i telefonen. Likevel så enkelte av turnuslegene på logistikk som en del av den medisinske vurderingen, hvor den ene avhenger av den andre.

Du må jo forklare sykehistorien minst tre ganger; først AMK Kirkenes, så AMK Tromsø, så vakthavende lege i Kirkenes, kanskje på UNN og kanskje må du fortelle den til en medisinsk vakthavende i tillegg til en kirurgisk. Så endrer sykehistorien seg... Du bruker utrolig mye tid på telefonen. (Kvinne 2, gruppe 3)

«Tillit til andre yrkesgrupper». Turnuslegene fortalte at de var overrasket over hvor godt samarbeidet med ambulansearbeiderne gikk. De følte at de hadde kompetanse å bidra med utover ambulansepersonellets og at de fikk respekt for det.

Jeg var egentlig overrasket over hvor greit det gikk og hvor godt de aksepterte en yngre lege, en uerfaren lege. Jeg forventet å bli mer overkjørt, men med én gang man viser at man tar litt grep eller begynner å gi litt ordre, så har det gått veldig bra! (Mann 2, gruppe 2)

Samarbeidet med AMK-sentralen var utfordrende - det var både tilfeller av kommunikasjonssvikt og tilfeller der AMK-sentralen overkjørte turnuslegene i spørsmål om transport og utrykning.

Jeg har måttet krangle én gang med AMK. Men til syvende og sist så må man bare etablere 
hvem som har ansvaret. Jeg husker ikke helt hva som feilet pasienten, men jeg ville ha flytransport. Så var det en eller annen AMK-operatør som begynte å krangle veldig. Så sa jeg at jeg ikke kan tvinge dem til å sende et fly, men jeg sa at jeg journalførte at dem hadde ansvaret for pasienten da. Nei det fikk jeg ikke gjøre. Så da fikk jeg til slutt et fly da. (Mann 1, gruppe 2)

Enkelte steder i Finnmark er ikke politiet tilgjengelig på vakt i nærmiljøet døgnet rundt. Lang utrykningstid førte til vanskelige situasjoner i forbindelse med vaktarbeid for turnuslegene. Det å skulle vente på politi i situasjoner som spesielt involverer rus og psykiatri, utfordret egensikkerheten til legene og andre involverte personer.

Vi måtte vente på politi fra et annet sted... Det var en som truet med å skyte seg selv, og hvis vi nærmet oss skulle han skyte alle rundt. Så satt vi der og ventet på politi. Ikke veldig kult.

(Kvinne 2, gruppe 1)

\section{Diskusjon}

Denne studien viser at turnusleger i kommuneturnus i Finnmark i perioden september 2015-februar 2016 opplevde at de ble tryggere på seg selv og det medisinske arbeidet under utrykning gjennom kommuneturnustjenesten. De følte seg bedre i stand til å vurdere behovet for å delta i utrykninger og fant at de hadde en viktig - og håndterbar - rolle som lege under utrykning. Det kan virke som om beslutningen om hvorvidt legen skulle delta i utrykning eller ikke ble fundert på et bedre grunnlag i løpet av turnustiden. Før tjenesten følte turnuslegene seg generelt gode nok i de fleste praktiske ferdigheter. Gjennom turnustjenesten erfarte de at dette stemte, men at praktiske gjøremål utenfor sykehus, og da spesielt på utrykning, ofte ikke var deres primære oppgave (8).

Spørreskjemaene viste at turnuslegene følte seg trygge på ferdigheter som manuelle hjertekompresjoner og sikring av frie luftveier, mens de var usikre på intraosseøs infusjon og pleurapunksjon ved pneumothorax. En relativt vanlig prosedyre som perifer venekanylering var turnuslegene bemerkelsesverdig lite trygge på å skulle gjennomføre. Utrykning med ambulansen på akutte turer var turnuslegene generelt moderat trygge på. Fritekstsvarene viste at særlig teamtrening var en ferdighet de gjerne skulle ha behersket bedre. Legens rolle i team, kommunikasjon og samarbeid, særlig med ambulansepersonell, ble nevnt spesifikt.

Det er tankevekkende legene følte at de hadde mangelfull beherskelse av praktiske ferdigheter, som venekanylering, og av ikke-tekniske ferdigheter. Å mestre arbeid i team og å være flink til å kommunisere er kjerneferdigheter innen akuttmedisinsk ledelse og noe turnusleger bør føle seg trygg på før kommuneturnus.

Denne lille studien kan ikke brukes til å sammenligne studiesteder eller sykehusturnus, og deltagerne i kommuneturnus hadde sin forutgående sykehusturnus fra ulike helseforetak. I denne sammenheng er det underlig at den felles trening i samhandling som akuttforskriften pålegger kommuner og helseforetak, erfaringsmessig sjelden gjennomføres (2).

Hensikten med studien var å prøve å få en bedre forståelse for hvorfor leger i vakt i kommunehelsetjenesten ikke alltid deltar på utrykning ved rød respons $(9,10)$. Fordi studien er kvalitativ og ikke ment for generalisering, kan man ikke uten videre overføre funnene til andre legevaktleger. Studien omfatter bare nyutdannede leger og beskriver derfor ikke de øvrige mer erfarne legene. Vi mener likevel våre funn kan ha betydning for opplæring og forberedelse av leger i sykehusturnus og bevisstgjøre dem på deres rolle i kommuneturnus.

Denne kvalitative analysen er basert på databasert teoriutvikling (7). På grunn av studiens design, med behov for å delta på innledende og avsluttende samlinger for turnuslegene, var det ikke mulig å oppfylle kravet om suksessiv analyse av hver datainnsamling før den neste, og antall informanter var på forhånd begrenset til alle årgangens turnusleger. Vi mener 
likevel at analysen har vært forsvarlig og at vi oppnådde metning slik at synspunktene i gruppen er dekket av vår beskrivelse.

\section{Konklusjon}

De deltagende turnuslegene var generelt fornøyd med sine egne praktiske ferdigheter før kommuneturnus. Ferdigheter som venekanylering, ledelse og kommunikasjon var noe de savnet bedre opplæring i. Gjennom turnustiden ble frykten for å være overflødig eller nytteløs ved akuttutrykninger snudd til en opplevelse av å kunne mestre spesielt logistikk og pasientvurdering.

Turnuslegene opplevde stor nytte av et tett samarbeid med ambulansetjenesten og følte seg respektert og verdifulle på utrykning. De så seg bedre i stand til å vurdere når det var hensiktsmessig å delta i utrykning.

\section{HOVEDBUDSKAP}

Turnusleger i Finnmark opplevde faglig vekst og mestring gjennom kommuneturnusen Legene ønsket bedre ferdigheter i ledelse og kommunikasjon

\section{LITTERATUR:}

1. Den norske legeforening. Norsk indeks for medisinsk nødhjelp. 3. utg. Stavanger: Laerdal Medical, 2009.

2. Forskrift om krav til og organisering av kommunal legevaktordning, ambulansetjeneste, medisinsk nødmeldetjeneste mv. (Akuttmedisinforskriften). 2015. Kapittel 2, § 6; kommunens ansvar for kommunal legevaktordning. https://lovdata.no/dokument/LTI/forskrift/2015-03-20-231 (8.11.2017).

3. Momyr M, Kindt PG. Akuttmedisinske hendelser utenfor sykehus. Hovedoppgave. Trondheim: Institutt for sirkulasjon og bildediagnostikk, Det medisinske fakultet, Norges teknisknaturvitenskapelige universitet, 2011.

4. Kindt PG, Momyr M, Sundland E et al. Prehospital akuttmedisin uten legevaktlege? Tidsskr Nor Legeforen 2013; 133: 1176 - 7. [PubMed][CrossRef]

5. Pell G. Use and misuse of Likert scales. Med Educ 2005; 39: 970 - , author reply 971. [PubMed][CrossRef]

6. Malterud K. Fokusgrupper som forskningsmetode for medisin og helsefag. Oslo, Universitetsforlaget, 2012.

7. Hartman J. Grundat teori, teorigenerering på empirisk grund. Lund: Studentlitteratur, 2001.

8. Hjortdahl M, Zakariassen E, Wisborg T. The role of general practitioners in the pre hospital setting, as experienced by emergency medicine technicians: a qualitative study. Scand J Trauma Resusc Emerg Med 2014; 22: 47. [PubMed][CrossRef]

9. Ellensen EN, Hunskaar S, Wisborg T et al. Variations in contact patterns and dispatch guideline adherence between Norwegian emergency medical communication centres-a cross-sectional study. Scand J Trauma Resusc Emerg Med 2014; 22: 2. [PubMed][CrossRef]

10. Zakariassen E, Hunskaar S. Involvement in emergency situations by primary care doctors on-call in Norway-a prospective population-based observational study. BMC Emerg Med 2010; 10: 5 . [PubMed][CrossRef]

Publisert: 12. desember 2017. Tidsskr Nor Legeforen. DOI: 10.4045/tidsskr.17.016o

Mottatt 15.2.2017, første revisjon innsendt 27.6.2017, godkjent 8.11.2017.

(C) Tidsskrift for Den norske legeforening 2020. Lastet ned fra tidsskriftet.no 